\title{
Tralk KAJIAN DESAIN KEMASAN TOLAK ANGIN DAN ANTANGIN
}

Volume 1, Nomor 1

Juli 2019,

(51-60)

\section{Muhammad Agus Faisal}

Program Studi Pengkajian Desain Komunikasi Visual

Program Pascasarjana Institut Seni Indonesia Yogyakarta

e-mail : isal.ahmadd01@gmail.com

\begin{abstract}
ABSTRAK
Penelitian ini mengkaji desain kemasan pada produk jamu atau obat herbal diantaranya Tolak Angin dan Antangin, dimana produk Antangin merupakan produk mee too yang muncul setelah produk Tolak Angin. Tujuan penelitian ini adalah untuk mengetahui bagaimana desain kemasan Tolak Angin dan Antangin. Penelitian ini termasuk dalam penelitian deskriptif kualitatif. Metode analisis yang digunakan adalah metode kritik seni yang terdiri dari empat tahapan diantaranya adalah tahap deskriptif, analisis formal, interpretasi, dan penilaian. Teknik pengumpulan data pada penelitian ini menggunakan teknik observasi dan dokumentasi dengan melihat langsung desain visual pada masing-masing kemasan. Hasil atau temuan yang didapatkan dalam penelitian ini adalah perbedaan yang terlihat dari desain kedua kemasan namun tampak sama apabila dilihat dari unsur warna yang digunakan pada kedua kemasan.
\end{abstract}

Kata kunci: Antangin, desain visual, kemasan, Tolak Angin

\section{ABSTRACT}

This study examines the design of packaging on herbal products or herbal remedies such as Tolak Angin and Antangin, where Antangin products are mee too products that appear after the product Tolak Angin. The purpose of this study is to find out how the design of Tolak Angin and Antangin. This research is included in qualitative descriptive research. The analytical method used is art criticism method consisting of four stages including descriptive stage, formal analysis, interpretation, and assessment. Data collection techniques in this study using observation and documentation techniques by looking directly at the visual design of each packaging. The results or findings obtained in this study are the differences seen from the design of the two packages but appear the same when viewed from the color elements used in both packaging.

Keyword: Antangin, visual design, packaging, Tolak Angin

\section{PENDAHULUAN}

Produk merupakan titik pusat dari kegiatan pemasaran. Produk merupakan hasil dari suatu perusahaan yang dapat ditawarkan ke pasar untuk di konsumsi dan merupakan alat dari suatu perusahaan untuk mencapai tujuan dari perusahaannya. Suatu produk harus memiliki keunggulan dari produk-produk yang lain baik dari segi kualitas, desain, bentuk, ukuran, kemasan, pelayanan, garansi, dan rasa agar dapat menarik minat konsumen untuk mencoba dan membeli produk tersebut.

Pengertian produk (product) menurut Kotler \& Armstrong, (Kotler, 2001, p. 346) adalah segala sesuatu yang dapat ditawarkan ke pasar untuk mendapatkan perhatian, dibeli, digunakan, atau dikonsumsi yang dapat memuaskan keinginan atau kebutuhan.

Seiring perkembangan zaman semakin banyak perusahaan industri bermunculan sehingga persaingan dalam dunia industri semakin ketat.
Agar produk yang dihasilkan perusahaan dapat dikenal oleh masyarakat dan menciptakan kebutuhan baru, maka salah satunya dapat ditunjang dengan desain kemasan yang menarik karena kemasan adalah hal yang paling tampak dari suatu produk dan merupakan persepsi awal konsumen terhadap daya tarik suatu produk. Hal ini didukung oleh Metcalf et al., (Metcalf, Jeffrey, \& Singh, 2012) bahwa desain kemasan produk penting bagi konsumen dalam mempengaruhi niat untuk membeli dan berniat untuk merekomendasikan produk tersebut kepada orang lain.

Proses persepsi seseorang dalam hal daya tarik suatu kemasan akan diserap otak sadar dan otak bawah sadar konsumen yang pada akhirnya banyak mempengaruhi reaksi atau tindakan konsumen di tempat penjualan. Hukum persepsi menunjukkan bahwa mata dan otak membutuhkan kesederhanaan dan keseimbangan dalam segala hal yang dilihat. Kemasan memiliki peranan penting dalam menentukan kesan konsumen bahwa 
terdapat kesamaan dengan produk yang ada dalam kemasan tersebut. Misalnya saja, kemasan yang lebih besar menggiring konsumen untuk percaya bahwa produk di dalamnya lebih banyak. Kemasan yang lebih tinggi tapi tipis menciptakan bayangan bahwa produk yang ada di dalamya lebih banyak daripada kemasan yang pendek tapi lebar, meskipun perbedaan ini mungkin akan hilang ketika adanya keistimewaan lain dari kemasan.

Daya tarik sebuah kemasan sangat penting karena berpengaruh dalam tindakan konsumen baik secara sadar maupun tanpa sadar. Daya tarik kemasan itu sendiri terbagi menjadi dua, yaitu daya tarik visual yang mengacu pada penampilan kemasan atau label suatu produk yang mencakup wama, bentuk, merek, ilustrasi, teks, serta tata letak, dan daya tarik praktis yang merupakan efektivitas dan efisiensi suatu kemasan yang ditujukan kepada konsumen maupun distributor/ pengecer.

Berdasarkan efek daya tarik visual kemasan, perusahaan terkadang menggunakan kemasan yang sangat mirip dengan saingan mereka yang sudah terkenal (pesaing utama). Hal ini disebut dengan produk me too yang berusaha untuk menciptakan pendapat yang baik dengan menggunakan stimulus generalization. Stimulus generalization terjadi ketika terdapat hubungan antara stimulus-respon yang telah ada. Stimulus baru yang paling mirip dengan yang sudah ada, kemungkinan besar akan menimbulkan respon yang sama. Dengan membuat kemasan yang sangat mirip seperti pesaing, perusahaan berharap agar setidaknya sebagian pendapat yang baik juga akan diberikan pada produk tersebut. Dalam hal ini yang dimaksudkan dengan pesaing adalah produk-produk yang sudah ada terlebih dahulu atau yang sudah terkenal dan produk tersebut memiliki pangsa pasar yang besar.

Untuk meyakinkan konsumen, maka pesaing biasanya membuat kemasan yang mirip dengan produk ternama yang bertujuan untuk menyampaikan pesan bahwa produknya memiliki citra dan kualitas yang baik pula seperti produk dengan merek yang sudah ternama (Wang, 2013). Praktek produk me too mungkin akan menyamarkan produk pesaing sebagai produk ternama, sehingga konsumen bisa menjadi bingung, apalagi jika ia berbelanja terburu-buru dan tidak hati-hati maka mungkin konsumen akan salah membeli. Dengan adanya produk me too ini konsumen akan semakin bingung dalam memilih suatu produk, atau bahkan sulit sekali membedakan antara produk pemimpin pasar dengan produk me too.

Peneliti memfokuskan penelitian ini pada produk obat masuk angin Antangin sirup yang diproduksi oleh PT. Dehorned Laboratories yang merupakan produk me too dari produk Tolak Angin cair. Dikatakan demikian karena keberadaan Tolak Angin lebih awal dibandingkan dengan Antangin.
Tolak Angin yang muncul pada tahun 1930 masih berbentuk butiran yang harus diseduh sebelum diminum dan beredar dalam bentuk cair pada tahun 1999. Tolak Angin dikemas dalam kotak karton yang berisi 12 sachet yang masing-masing sachet berisi $15 \mathrm{ml}$.

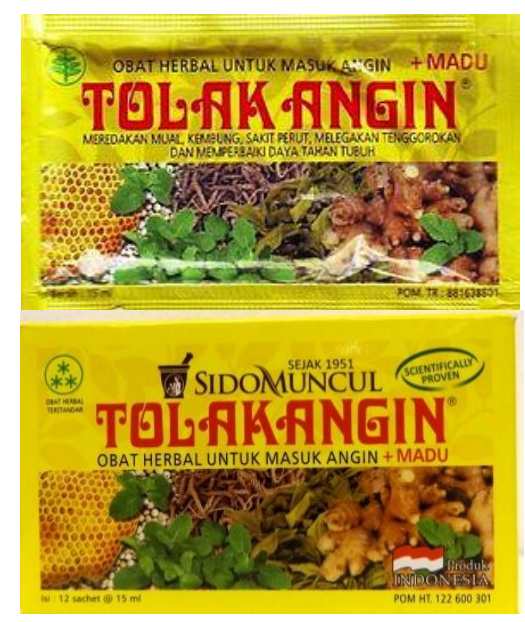

Gambar 1. Kemasan produk Tolak Angin ( sumber : dokumen pribadi penulis )

Antangin sebagai obat masuk angin yang berbentuk kaplet baru muncul pada tahun 1970 dengan nama Antangin masih belum digarap dengan benar dan barn ditangani secara serius bersamaan dengan pembaharuan manajemen pada tahun 1997. Setelah cukup berhasil dengan Antangin dalam bentuk kaplet, sejak Januari 2003 PT. Deltomed Laboratories meluncurkan Antangin cair dengan kemasan yang sama-sama berwama kuning juga desain kemasan yang tak jauh berbeda dengan Tolak Angin. Berbeda dengan Tolak Angin, Antangin dikemas dalam kotak karton yang berisi 10 sachet. Namun, masing-masing sachet juga berisi $15 \mathrm{ml}$ seperti pada Tolak Angin.

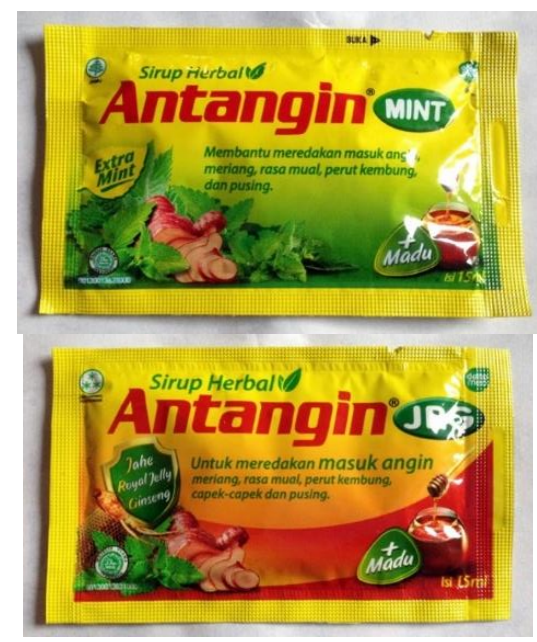

Gambar 2. Kemasan produk Tolak Angin dan Antangin (sumber : dokumen pribadi penulis ) 
Tolak Angin dan Antangin berbeda dengan produk jamu lainnya yang harus diseduh terlebih dahulu sebelum diminum. Tolak Angin dan Antangin hadir berupa sirup dengan kemasan saset yang praktis dalam penggunaannya. Produk ini sering dijumpai di pasaran, bahkan untuk Tolak Angin tidak hanya dipasarkan di dalam negeri tetapi sudah sampai ke luar negeri. Produk Antangin merupakan produk mee too yang hadir setelah produk Tolak Angin yang ada di pasaran. Desain kemasan pada Antangin jika dilihat sekilas hampir sama dengan desain pada Tolak Angin, dimana background yang digunakan kedua produk ini berwarna kuning, pada bagian tipografi nama mengunakan warna merah. Secara keseluruhan unsur warna pada kedua kemasan ini menggunakan warna kuning, merah, dan hijau. Unsur warna ini yang membuat desain kemasan nampak sama apabila dilihat secara sekilas. Hal ini yang menjadi alasan peneliti untuk mengetahui kajian desain kemasan pada produk Tolak Angin dan Antangin untuk mengetahui bagaimana tata visual atau layout dan bagaimana perwujudan gambar atau ilustrasi pada kemasan produk.

\section{KAJIAN PUSTAKA}

\section{Desain Kemasan}

Hermawan Kartajaya, seorang pakar di bidang pemasaran mengatakan bahwa teknologi telah membuat kemasan berubah fungsi, dulu orang bilang "Packaging protects what it sells (Kemasan melindungi apa yang dijual)". Sekarang, "Packaging sells what it protects (Kemasan menjual apa yang dilindungi)" (Kartajaya, 1996). Dengan kata lain, kemasan bukan lagi sebagai pelindung atau wadah tetapi harus dapat menjual produk yang dikemasnya. Sekarang ini kemasan sudah berfungsi sebagai media komunikasi sehingga dalam meluncurkan suatu produk (Silayoi \& Speece, 2005) salah satu tugas yang penting adalah membuat kemasannya stands out, lain daripada yang lain dan unik. Semua produk yang dijual dipasaran dalam kategori yang sama akan diletakkan pada rak yang sama, sehingga kesan pada produk baru dibuat berbeda dengan produk lain agar produk baru tidak "tenggelam". Sebelum mencoba isinya, konsumen akan menangkap kesan yang dikomuniksikan oleh kemasan. Dengan demikian kemasan produk baru tersebut harus mampu "beradu" dengan kemasan produk-produk lainnya (Hermawan Kertajaya, 1996).

Kemasan merupakan salah satu pemecahan masalah untuk menarik konsumen karena berhadapan langsung dengan konsumen. Masyarakat kita merupakan "low involvement view of a passive consumer". Mereka mempunyai kecenderungan lebih banyak menerima apabila melihat kemasan yang menarik lebih mengingatnya dan akan percaya terhadap produk tersebut, walaupun produk tersebut tidak seperti yang dibayangkan. Kemasan mempunyai presentase yang besar untuk menjual produk.

Membuat kemasan tampil menarik dibutuhkan strategi kreatif yang merupakan penerapan dari desain kemasan. Beberapa hal yang dapat dilakukan mengenai strategi kreatif ini adalah dengan memodifikasi sisisisi tertentu dari suatu produk, antara lain (Nugroho, 2006)

1. Warna

Konsumen melihat warna jauh lebih cepat daripada melihat bentuk atau rupa. Dan warnalah yang pertama kali terlihat bila produk berada di tempat penjualan. Warna dengan daya pantul tinggi akan lebih terlihat dari jarak jauh dan direkomendasikan sebagian besar kemasan, karena memilik daya tarik dan dampak yang lebih besar. Tapi selain unsur keterlihatan harus dipertimbangkan pula faktor kekontrasan terhadap warna-warna pendukung lainnya.

2. Bentuk

Bentuk majalah merupakan pendukung utama yang membantu terciptanya seluruh daya tarik visual. Namun tidak ada prinsip baku yang menentukan bentuk fisik dari sebuah kemasan karena ini biasanya ditentukan oleh sifat produk, pertimbangan mekanis, kondisi marketing, pertimbangan pemajangan, dan oleh cara penggunaan kemasan tersebut.

3. Merek atau logo

Identitas suatu produk sangat diperlukan sekali. Hal ini untuk membedakan kemasan yang kita buat dengan kemasan yang lain. Tujuan lain dengan adanya merek atau logo adalah mengenalkan produk kita kepada masyarakat dalam bentuk nonproduk. Misalnya dalam pamflet, spanduk dan alat komunikasi yang lain. Dengan adanya simbolsimbol dalam merek atau logo, maka masyarakat akan cepat mengenali produk kita. Membuat sebuah logo hendaknya yang simple, yang menggambarkan ciri khas, mudah untuk dijelaskan, menggugah, mengandung keaslian dan tidak mirip dengan logo-logo produk lain.

4. Ilustrasi

Ilustrasi merupakan salah satu unsur penting yang sering digunakan dalam komunikasi sebuah kemasan karena sering dianggap sebagai bahasa universal yang dapat menembus rintangan yang ditimbulkan oleh perbedaan bahasa kata-kata. Ilustrasi, dalam hal ini termasuk fotografi, dapat mengungkapkan suatu yang lebih cepat dan lebih efektif daripada teks. Pembubuhan ilustrasi dalam suatu produk media harus didasarkan pada fungsinya yang khas. Suatu kemasan dipandang akan lebih berdaya tarik bila dibubuhi ilustrasi, kecuali untuk kondisi tertentu mungkin tidak diperlukan ilustrasi.

5. Tipografi 
Teks pada produk media merupakan pesan katakata, digunakan untuk menjelaskan produk yang ditawarkan dan sekaligus mengarahkan sedemikian rupa agar konsumen bersikap dan bertindak sesuai dengan harapan produsen. Type huruf harus disesuaikan dengan tema dan tujuan dari produk itu sendiri. Maka disinilah diperlukan kejelian dalam memilih huruf atau font yang sesuai atau menjiwai dari produk tersebut.

\section{Tata Visual atau Layout}

Menata visual berarti meramu seluruh aspek grafis, meliputi warna, bentuk, merek, ilustrasi, tipografi menjadi suatu kemasan baru yang disusun dan ditempatkan pada halaman kemasan secara utuh dan terpadu.

\section{Prinsip Desain}

Prinsip dasar desain merupakan pengorganisasian unsur-unsur dasar desain dengan memperhatikan prinsip-prinsip dalam menciptakan dan mengaplikasikan kreativitas. Frank Jefkins (Jefkins, 1997, p. 245) mengelompokkan prinsip-prinsip desain menjadi: kesatuan, keberagaman, keseimbangan, ritme, keserasian, proporsi, skala, dan penekanan.

1. Kesatuan (unity)

Kesatuan merupakan sebuah upaya untuk menggabungkan unsur-unsur desain menjadi suatu bentuk yang proporsional dan menyatu satu sama lain ke dalam sebuah media. Kesatuan desain merupakan hal yang penting dalam sebuah desain, tanpa ada kesatuan unsur-unsur desain akan terpecah berdiri sendiri-sendiri tidak memiliki keseimbangan dan keharmonisan yang utuh.

2. Keberagaman (variety)

Keberagaman dalam desain bertujuan untuk menghindari suatu desain yang monoton. Untuk itu diperlukan sebuah perubahan dan pengkontrasan yang sesuai. Adanya perbedaan besar kecil, tebal tipis pada huruf, pemanfaatan pada gambar, perbedaan warna yang serasi, dan keragaman unsur-unsur lain yang serasi akan menimbulkan variasi yang harmonis.

3. Keseimbangan (balance)

Keseimbangan adaslah bagaimana cara mengatur unsur-unsur yang ada menjadi sebuah komposisi yang tidak berat sebelah. Keseimbangan dapat tercapai dari dua bagian, yaitu secara simetris yang terkesan resmi/formal yang tercipta dari sebuah paduan bentuk dan ukuran tata letak yang sama, sedangkan keseimbangan asimetris memberi kesan informal, tapi dapat terlihat lebih dinamis yang terbentuk dari paduan garis, bentuk, ukuran, maupun tata letak yang tidak sama namun tetap seimbang.

\section{Ritme/irama (rhythm)}

Aliran secara keseluruhan terhadap desain selalu menyiratkan irama yang nyaman. Suatu gerak yang dijadikan sebagai dasar suatu irama dan ciri khasnya terletak pada pengulanganpengulangan yang dilakukan secara teratur yang diberi tekanan atau aksen. Ritme membuat adanya kesan gerak yang menyiratkan mata pada tampilan yang nyaman dan berirama.

5. Keserasian (harmony)

Suptandar (Suptandar, 1995, p. 19) mengartikan keserasian sebagai usaha dari berbagai macam bentuk, bangun, warna, tekstur, dan elemen lain yang disusun secara seimbang dalam suatu komposisi utuh agar nikmat untuk dipandang. Keserasian adalah keteraturan di antara bagian-bagian suatu karya.

\section{Proporsi (proportion)}

Proporsi merupakan perbandingan antara suatu bilangan dari suatu objek atau komposisi (Kusmiati, Astuti, \& Suptandar, 1999, p. 19) Bisa dikatakan bahwa proporsi merupakan kesesuaian ukuran dan bentuk hingga tercipta keselarasan dalam sebuah bidang. Terdapat tiga hal yang berkaitan dengan masalah proporsi, yaitu penempatan susunan yang menarik, penentuan ukuran dan bentuk yang tepat, dan penentuan ukuran sehingga dapat diukur atau disusun sebaik mungkin.

\section{Skala (scale)}

Skala adalah ukuran relatif dari suatu objek, jika dibandingkan terhadap objek atau elemen lain yang telah diketahui ukurannya (Kusmiati et al., 1999, p. 14). Skala berhubungan dengan jarak pandang atau penglihatan dengan unsur-unsur yang telah dimunculkan (faktor keterbacaan). Skala juga sangat berguna bagi terciptanya kesesuaian bentuk atau objek dalam suatu desain.

8. Penekanan (emphasis)

Frank Jefkins (Jefkins, 1997, p. 246) menyebutkan bahwa: "Dalam penekanan, all emphasis is no emphasis, bila semua ditonjolkan, maka yang terjadi adalah tidak ada hal yang ditonjolkan". Adanya penekanan dalam desain merupakan hal yang penting untuk menghindari kesan monoton. Penekanan dapat dilakukan pada jenis huruf, ruang kosong, warna, maupun yang lainnya akan menjadikan desain menjadi menarik bila dilakukan dalam proporsi yang cukup dan tidak berlebihan.

\section{METODE PENELITIAN}

Penelitian ini menggunakan pendekatan penelitian deskriptif kualitatif. Penelitian deskriptif adalah penilitian yang bertujuan menggambarkan dan menginterpretasi objek yang diteliti sesuai dengan keadaan yang sebenarnya. Penelitian ini menggunakan pendekatan kualitatif yang menghasilkan data deskriptif berupa katakata tertulis maupun lisan dari subjek dan objek yang diamati. 
Menurut Sugiyono (Sugiyono, 2013, p. 15), dalam penelitian kualitatif instrumennya adalah orang atau human instrument, yaitu peneliti itu sendiri. Untuk dapat dapat menjadi instrumen, maka peneliti harus memiliki bekal teori dan wawasan yang luas, sehingga mampu bertanya, menganalisis, memotret, dan mengkonstruksi situasi sosial yang diteliti menjadi lebih jelas dan bermakna.

Untuk mengkaji desain pada kemasan tolak angin dan antangin, setiap desain kemasan dianalisis dengan pendekatan kritik seni yang dikemukakan Edmund Burke Feldman (Feldman, 1967) yang terdiri dari empat tahapan yakni: tahap deskriptif yang didalamnya hanya menguraikan unsur-unsur, tahap analisis formal yaitu membahas bagaimana elemen-elemen dasar dalam suatu karya tersusun menjadi suatu tampilan visual, tahap intepretasi yaitu menafsirkan kajian desain dalam kemasan, dan yang keempat adalah tahap penilaian yakni dengan melihat persamaan dan perbedaan antara kedua desain kemasan.

Pengumpulan data dilakukan dengan observasi ke toko atau apotek yang menjual produk jamu masuk angin. Teknik observasi didasarkan atas pengamatan secara langsung atau tidak langsung terhadap objek yang di teliti secara sistematis. Metode pengumpulan data dengan cara observasi dan dokumentasi berupa data visual, yaitu melakukan pengamatan pada kemasan. Pengamatan tentu menjadi hal penting karena dalam penelitian ini bentuk dan tampilan visual desain sangat menentukan proses pembacaan makna dan isinya, terutama pada tahapan analisis interpretasi.

Dalam pengamatan ini, metode yang digunakan adalah pengamatan tidak terlibat (nonparticipatory observation). Pengamatan tidak terlibat yang dilakukan oleh peneliti bertujuan untuk melihat bagaimana desain kemasan pada Tolak Angin dan Antangin. Teknik pengamatan dengan melihat aspek grafis pada desain kemasan masing-masing produk Tolak Angin dan Antangin.

Teknik analisis data menggunakan pendekatan kritik seni yang dikemukakan oleh Edmund Burke Feldman (Feldman, 1967) Teknik ini terdiri dari empat tahapan, yaitu deskripsi, analisis formal, interpretasi, dan penilaian.

Deskripsi adalah suatu proses pengumpulan data yang tersaji langsung kepada pengamat. Dalam tahap ini perlu dihindari penarikan kesimpulan yang melibatkan kesan pribadi yang sifatnya ilusif atau imajinatif. Peneliti dituntut untuk menyajikan keterangan secara objektif, yang bersumber pada desain kemasan yang diamati.

Dalam tahap analisis formal, tugas peneliti adalah menguraikan mutu garis, bentuk, warna, pencahayaan dan penataan unsur-unsur visual yang terdiri dari warna, huruf, dan ilustrasi pada kemasan.

Interpretasi merupakan metode menganalisis suatu desain visual. Dalam hal ini merupakan suatu proses ketika peneliti mengemukakan arti desain visual setelah melakukan penyelidikan yang cermat pada kemasan.

Penilaian dilakukan dengan menentukan kadar artistik dan faedah estetiknya. Penilaian orisinalitas adalah instrumen penilaian kritis yang menjelaskan desain kemasan, yakni dengan mengidentifikasi masalah penataan layout yang terdiri dari huruf, warna, dan ilustrasi pada kemasan.

\section{PEMBAHASAN}

\section{Desain Kemasan Tolak Angin \\ 1. Tolak Angin Obat Herbal untuk Masuk Angin ( + Madu)}

a. Desain Kemasan Bagian Depan

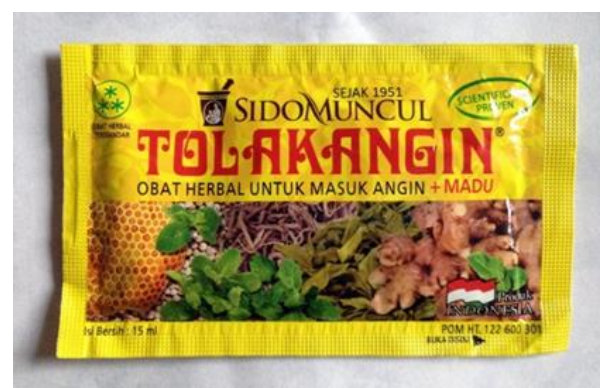

Gambar 3. Kemasan Tolak Angin (+ Madu) bagian depan ( sumber : dokumen pribadi penulis )

Desain kemasan yang digunakan pada background kemasan menggunakan warna kuning yang dikombinasikan dengan corak daun berwarna orange muda yang dibuat transparan pada bagian atas kemasan yang berisi tipografi tulisan dan pada bagian bawah terdapat gambar ilustrasi foto dengan teknik penggabungan. Headline kemasan terdapat pada kata "TOLAK ANGIN" yang merupakan nama dari produk dengan menggunakan warna merah jenis font "serif".

Pada sub headline terdapat logo dari PT SIDOMUNCUL beserta tulisan "SIDOMUNCUL" yang berwarna coklat dan diatasnya terdapat tahun berdirinya perusahaan yaitu "sejak 1951". Pada bagian bawah headline terdapat tulisan "OBAT HERBAL UNTUK MASUK ANGIN + MADU" yang berwarna hitam dan berwarna merah pada kalimat + MADU, yang berguna untuk penekanan jenis dari produk Tolak Angin.

Pada bagian bawah terdapat ilustrasi dengan media fotografi yang disebut dengan teknik potong perbagian lalu di tata secara tumpang tindih antara satu dengan lainnya membentuk persegi panjang. Subjek yang terdapat dalam foto antara lain: madu 
yang masih disarangnya, daun mint, jahe dan beberapa rempah-rempah pilihan.

Pada bagian kiri atas terdapat logo dari obat herbal terstandar sedangkan pada bagian kanan atas terdapat tulisan "SCIENTIFICALLY PROVEN" yang terletak di dalam garis berbentuk oval.

Pada bagian kanan bawah kemasan terdapat bendera merah putih dan tulisan produk INDONESIA yang bertujuan untuk menjelaskan kalau Tolak Angin merupakan produk asli dari Indonesia yang dibawahnya terdapat juga nomor POM, sedangkan pada bagian kiri bawah kemasan terdapat penjelasan isi dari produknya yaitu $15 \mathrm{ml}$.

Layout kemasan dari Tolak Angin yaitu asimetris dengan dibagi menjadi dua bagian, dimana bagian atas berisikan beberapa tipografi tulisan, superti Tolak Angin, sidomuncul dll. Sedangkan pada bagian bawah terdapat ilustrasi foto yang berbentuk persegi panjang yang berisikan beberapa foto yang disusun dengan teknik potong perbagian dan ditata secara tumpang tindih antara satu dengan yang lainnya.

b. Desain Kemasan Bagian Belakang

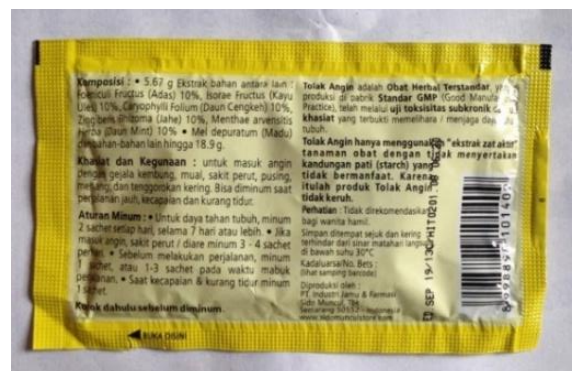

Gambar 4 Kemasan Tolak Angin (+ Madu) bagian belakang ( sumber : dokumen pribadi penulis )

Pada bagian belakang kemasan juga menggunakan warna kuning muda dan terdapat beberapa kalimat yang berisikan mengenai komposisi, khasisat dan kegunaan, aturan minum dengan font berwarna hitam dan tulisan "kocok dulu sebelum diminum" yang di beri efek bold untuk mempertegas perintah yang dianjurkan.

\section{Tolak Angin Obat Herbal untuk Masuk Angin (Bebas Gula)}

a. Desain Kemasan Bagian Depan

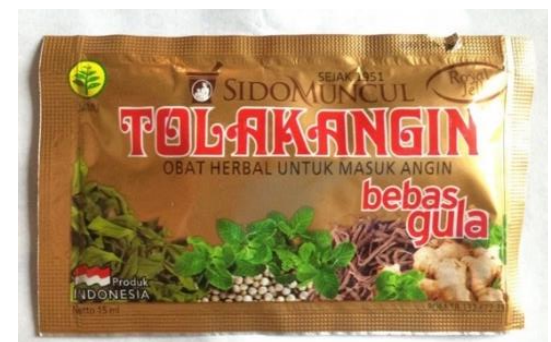

Gambar 5 Kemasan Tolak Angin (Bebas Gula) bagian depan ( sumber : dokumen pribadi penulis )
Desain kemasan yang digunakan pada background kemasan menggunakan warna coklat muda yang dikombinasikan dengan tipografi tulisan pada bagian atas dan pada bagian bawah terdapat gambar ilustrasi foto dengan teknik penggabungan. Headline kemasan terdapat pada kata "TOLAK ANGIN" yang merupakan nama dari produk dengan menggunakan warna merah jenis font "serif".

Pada sub headline terdapat logo dari PT SIDOMUNCUL beserta tulisan "SIDOMUNCUL" yang berwarna coklat tua dan diatasnya terdapat tahun berdirinya perusahaan yaitu "sejak 1951". Pada bagian bawah headline terdapat tulisan "OBAT HERBAL UNTUK MASUK ANGIN BEBAS GULA" yang berwarna hitam dan berwarna merah pada kalimat BEBAS GULA, yang berguna untuk penekanan jenis dari produk Tolak Angin.

Pada bagian bawah terdapat ilustrasi dengan media fotografi yang disebut dengan teknik potong perbagian lalu di tata secara tumpang tindih antara satu dengan lainnya membentuk persegi panjang. Subjek yang terdapat dalam foto antara lain: daun mint, jahe dan beberapa rempah-rempah pilihan.

Pada bagian kiri atas terdapat logo dari obat herbal terstandar sedangkan pada bagian kanan atas terdapat tulisan "Royal Jelly" yang terletak di dalam garis berwarna coklat berbentuk oval.

Pada bagian kiri bawah kemasan terdapat bendera merah putih dan tulisan produk INDONESIA yang bertujuan untuk menjelaskan kalau Tolak Angin merupakan produk asli dari Indonesia yang dibawahnya terdapat juga penjelasan isi dari produknya yaitu $15 \mathrm{ml}$, sedangkan pada bagian kanan bawah kemasan terdapat nomor POM dari produk Tolak Angin.

Layout kemasan dari Tolak Angin yaitu asimetris dengan dibagi menjadi dua bagian, dimana bagian atas berisikan beberapa tipografi tulisan, superti Tolak Angin, sidomuncul dll. Sedangkan pada bagian bawah terdapat ilustrasi foto yang berbentuk persegi panjang yang berisikan beberapa foto yang disusun dengan teknik potong perbagian dan ditata secara tumpang tindih antara satu dengan yang lainnya.

b. Desain Kemasan Bagian Belakang

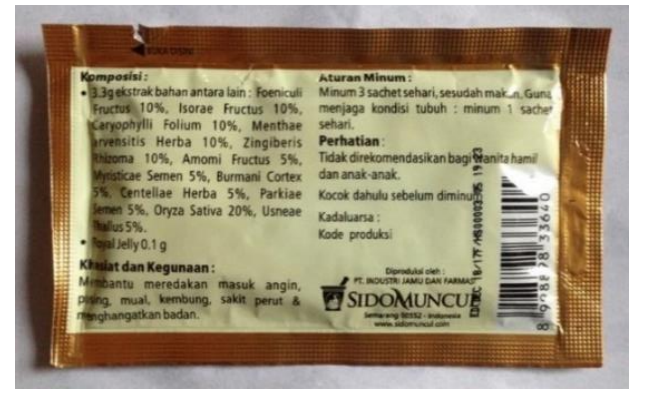

Gambar 6. Kemasan Tolak Angin (Bebas Gula) bagian belakang ( sumber: dokumen pribadi penulis ) 
Pada bagian belakang kemasan menggunakan warna kuning muda dan terdapat beberapa kalimat yang berisikan mengenai komposisi, khasisat dan kegunaan, aturan minum dengan font berwarna hitam dan detail produksi ada pada bagian kanan bawah kemasan.

\section{Desain Kemasan Antangin \\ 1. Antangin JRG}

a. Desain Kemasan Bagian Depan

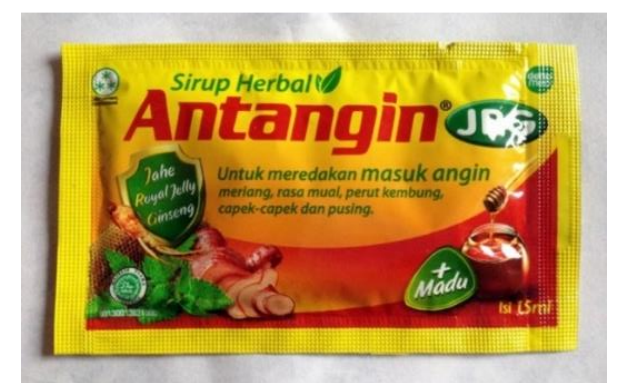

Gambar 7. Kemasan Antangin JRG bagian depan ( sumber: Dokumen Pribadi Penulis )

Desain kemasan Antangin JRG menggunakan warna kuning yang dijadikan background dengan kombinasi warna merah dibawahnya dan gradasi warna orange. Tulisan Antangin berwarna merah dengan jenis font "San-Serif" yang dijadikan headline dikarenakam ukuran fontnya paling besar dari font lainnya. Di samping tulisan Antangin terdapat tulisan JRG dengan warna putih yang diletakkan dalam bidang oval berwarna hijau. Diatas tulisan Antangin terdapat tulisan "sirup herbal" yang menggunakan jenis font "San-Serif" yang berwarna hijau. Pada tengah kemasan terdapat kalimat "Untuk meredakan masuk angin, meriang, rasa mual, perut kembung, capek-capek dan pusing" dengan font berwarna hijau.

Pada bagian kiri bawah kemasan terdapat ilustrasi foto yang disebut dengan teknik penggabungan beberapa foto yang di tata secara tumpang tindih satu dengan lainnya dengan ilustrasi foto diantaranya terdapat Jahe, Ginseng, daun mint, sarang madu. Pada bagian atas ilustrasi terdapat kata "Jahe, Royal Jelly, Ginseng" dengan font berwarna kuning untuk huruf pertama dan putih untuk huruf selanjutnya. Penggunaan warna kuning untuk huruf pertama bertujuan untuk menjelaskan kepanjangan dari JRG yang terdapat pada samping kanan tulisan Antangin. Bagian kanan bawah pada desain kemasan terdapat ilustrasi foto madu yang ditaruh di dalam toples dan terdapat juga tongkat untuk mengambil madu di atasnya, dan terdapat tulisan "+ Madu" yang menggunakan warna putih yang berada di depan segitiga tumpul dengan perpaduan warna antara kuning dan hijau.

Pada bagian pojok kiri atas kemasan terdapat logo obat herbal terstandar sedangkan pada bagian kanan atas kemasan terpadat logo deltomeo yang merupakan produsen dari sirup herbal Antangin. Pada bagian kiri bawah kemasan terdapat logo halal sedangkan bagian kanan bawah terdapat berat dari isi produknya yaitu $15 \mathrm{ml}$.

Ditinjau secara keseluruhan alur dari desain kemasan membentuk $\mathrm{Z}$ atau zigzag dengan cara membacanya dari kiri atas kekanan lalu turun ke kiri bawah dan kenanan bawah.

b. Desain Kemasan Bagian Belakang

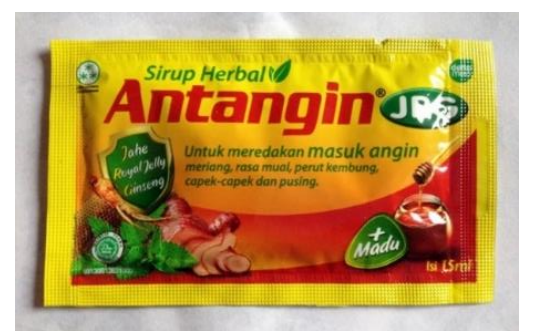

Gambar 8. Kemasan Antangin JRG bagian belakang ( sumber: dokumen pribadi penulis )

Pada bagian kiri atas terdapat tulisan Antangin yang berwarna merah, di sampingnya terpadat tulisan JRG dengan warna putih yang terdapat di dalam bentuk oval dan diatasnya terpadat tulisan sirup herbal yang berwarna hijau. Pada bagian bawah tulisan Antangin terdapat tulisan "Rasakan sensasi kenikmatan dan khasiat minut Antangin JRG dengan air hangat atau teh favorit Anda" lalu bagian bawahnya terdapat ilustrasi foto secanggir teh dan terdapat tulisan "Dicampur teh lebih nikmat" yang terletak di dalam lingkaran berwarna hijau. Bagian kanan atas kemasan terdapat tulisan "Untuk meredakan masuk angin" ditulis menggunakan font berwarna hijau. Sedangkan untuk sisa bagian kemasan kurang lebih $3 / 4$ bagian dari kemasan belakang menjelaskan mengenai detail dari produk Antangin yang terdiri dari komposisi, khasiat \& kegunaan, dosis dewasa, dosis anak-anak (6-12 th), anjuran minum, barkot produk, kode \& kadaluarsa, nomor POM HT, dan detail produksi.

\section{Antangin MINT}

\section{a. Desain Kemasan Bagian Depan}

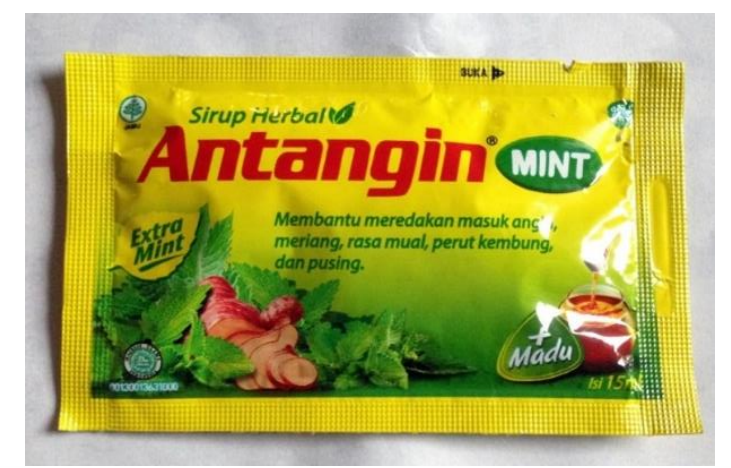

Gambar 9 Kemasan Antangin MINT bagian depan (sumber: dokumen pribadi penulis ) 
Desain kemasan Antangin MINT sama dengan Antangin JRG menggunakan warna kuning sebagai background namun dengan kombinasi gradasi warna hijau dibawahnya. Tulisan Antangin berwarna merah dengan jenis font "San-Serif" yang dijadikan headline dikarenakam ukuran fontnya paling besar dari font lainnya. Di samping tulisan Antangin terdapat tulisan MINT dengan warna putih yang diletakkan dalam bidang oval berwarna hijau. Diatas tulisan Antangin terdapat tulisan "sirup herbal" yang menggunakan jenis font "SanSerif" berwarna hijau dengan penambahan ilustrasi daun setelah tulisan. Pada bagian tengah kemasan terdapat kalimat "Untuk meredakan masuk angin, meriang, rasa mual, perut kembung, dan pusing" dengan font berwarna hijau. Khasiat Antangin MINT disini jelas berbeda dengan Antangin JRG dimana pada Antangin MINT tidak ada tulisan untuk meredakan capek-capek.

Pada bagian kiri bawah kemasan terdapat ilustrasi foto yang disebut dengan teknik penggabungan beberapa foto yang di tata secara tumpang tindih satu dengan lainnya dengan ilustrasi foto diantaranya terdapat Jahe, dan daun mint. Pada bagian atas ilustrasi terdapat kata "Extra Mint" dengan font berwarna hijau yang terletak di dalam gambar daun berwarna kuning. Bagian kanan bawah pada desain kemasan terdapat ilustrasi foto madu yang ditaruh di dalam toples dan terdapat juga tongkat untuk mengambil madu di atasnya, dan terdapat tulisan "+ Madu" yang menggunakan warna putih yang berada di depan segitiga tumpul dengan perpaduan warna antara kuning dan hijau.

Pada bagian pojok kiri atas kemasan terdapat logo JAMU sedangkan pada bagian kanan atas kemasan terpadat logo deltomeo yang merupakan produsen dari sirup herbal Antangin. Pada bagian kiri bawah kemasan terdapat logo halal sedangkan bagian kanan bawah terdapat berat dari isi produknya yaitu $15 \mathrm{ml}$.

Ditinjau secara keseluruhan alur dari desain kemasan membentuk $\mathrm{Z}$ atau zigzag dengan cara membacanya dari kiri atas kekanan lalu turun ke kiri bawah dan kenanan bawah.

b. Desain Kemasan Bagian Belakang

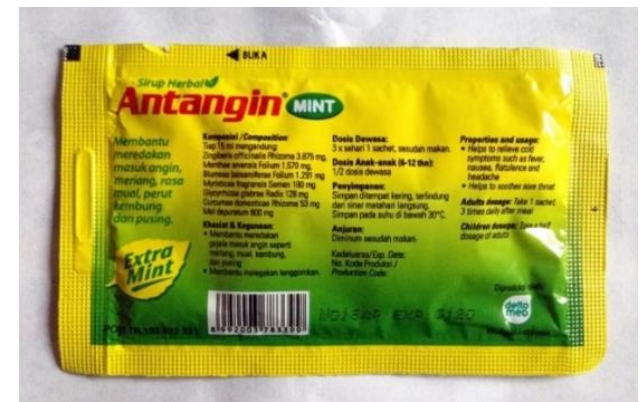

Gambar 10 Kemasan Antangin MINT bagian belakang ( sumber: dokumen pribadi penulis )
Pada bagian kiri atas terdapat tulisan Antangin yang berwarna merah, di sampingnya terpadat tulisan MINT dengan warna putih yang terdapat di dalam bentuk oval dan diatasnya terpadat tulisan sirup herbal yang berwarna hijau. Pada bagian bawah tulisan Antangin terdapat tulisan "Membantu meredakan masuk angin, meriang, rasa mual, perut kembung, dan pusing" lalu bagian bawahnya terdapat gambar daun kuning yang didalamnya terdapat tulisan "Extra Mint". Bagian kanan atas kemasan terdapat tulisan "Untuk meredakan masuk angin" ditulis menggunakan font berwarna hijau. Sedangkan untuk sisa bagian kemasan kurang lebih $3 / 4$ bagian dari kemasan belakang menjelaskan mengenai detail dari produk Antangin yang terdiri dari komposisi, khasiat \& kegunaan, dosis dewasa, dosis anak-anak (6-12 th), penyimpanan, anjuran minum, barkot produk, kode \& kadaluarsa, nomor POM TR, dan detail produksi.

\section{Analisis \\ 1.Analisis Kemasan Tolak Angin + Madu}

Desain kemasan pada tolak angin + madu mengggunakan warna kuning untuk background, dimana warna kuning ini memberikan kesan hangat. Jadi pemilihan warna kuning sebagai background mewakili arti dari obat herbal tersebut dimana jika diminum memberikan kehangatan pada tubuh. Untuk warna pada tipografi yang utama menggunakan warna merah untuk mempertegas nama dari brand Tolak Angin. Ilustrasi yang terdapat pada kemasan yaitu "tolak angin + madu" mengilustrasikan bahan dasar pembuatan jamu tolak angin, dalam ilustrasinya terdapat beberapa rempah rempah atau bisa dibilang menggunakan bahan alamiah. Ilustrasi ini mempertegaskan jika obat tersebut atau bisa dikatakan sebagai jamu, terbuat dari bahan alami tanpa menggunakan bahan kimia. Pada penataan komposisi dari ilustasi dibuat pada bidang persegi dengan teknik penggabungan beberapa foto. Penekanan pada kemasan tersebut terdapat pada madu dengan warna tipografi yang menggunakan warna merah. Pada bagian kiri kemasan digambarkan ilustrasi dengan sarang madu yang berukuran besar. Secara keseluruhan layout yang dihasilkan dari desain kemasan tolak angin + madu yaitu simetris, hal ini terlihat pada penataan unsur satu dan unsur lainnya yang seimbang. Hal ini terlihat pada kemasan yang dibagi menjadi dua bagian yaitu kanan dan kiri sehingga terlihat penataan yang seimbang. Unsur warna merah, kuning dan hijau yang digunakan pada kemasan ini menimbulkan kesan harmonis.

Desain pada bagian atas terdapat logo dari pembuat obat herbal, dimana terdapat "tahun 1951" yang bertujuan untuk menegaskan bahwa berdirinya produsen obat tersebut sudah sangat lama sejak tahun 1951 dan hingga sekarang masih 
terkenal di dunia obat herbal atau bisa dikatakan jamu asli dari Indonesia.

Desain pada bagian kanan bawah terdapat bendera merah putih dan tulisan produk Indonesia. Dalam hal ini bertujuan untuk menegaskan jika produk ini asli buatan anak bangsa Indonesia, dan produk ini sudah beredar di beberapa negara tetangga dan negara maju. Jadi warga Indonesia harus bangga dengan produk obat herbal asli Indonesia yang sudah dipasarkan di beberapa negara atau sudah mendunia.

\section{Analisis Kemasan Tolak Angin Bebas Gula}

Tolak angin bebas gula merupakan produk baru yang dipasarkan oleh PT sido muncul. Produk ini baru dijumpai dipasaran belakangan tahun ini. Desain kemasan produk ini menggunakan warna coklat untuk backgorund yang merupakan unsur bumi, dimana dalam hal ini bahan dasar dari obat tersebut adalah alamiah, rempah-rempah asli, dan tampa campuran bahan kimia. Hal ini bisa dilihat pada kemasan yang terdapat ilustrasi beberapa rempah-rempah dengan menggunakan beberapa foto yang digabung jadi satu. Penataan ilustrasi dibuat menyadu dengan latar background, hal ini membuat kesan dinamis dan harmonis. Jenis tipogafi yang digunakan sama dengan desain kemasan yang satunya. Warna merah masih digunakan untuk warna pada nama dari produk tersebut, warna merah lebih memberi fokus tersendiri dan penegasan dari nama obat herbal Tolak Angin.

Penegasan lainnya terdapat pada bagian kalimat bebas gula yang menggunakan warna merah. Hal ini bertujuan untuk menjelaskan jika obat herbal atau produk Tolak Angin yang ini bebas dari gula. Selain dari tulisan tersebut juga bisa dilihat tidak adanya ilustrasi dari madu, dimana madu memberikan kesan manis atau terdapat unsur gula didalamnya. Secara keseluruhan komposisi dari kemasan ini berat pada bagian kanan kemasan, karena terdapat kalimat "bebas gula" dengan menggunakan warna merah yang merupakan fokus dari kemasan ini. Keterbacaan dari layout ini membacaannya seperti huruf Z, dari bagian kiri ke kanan lalu ke bagian bawah kiri selanjutnya ke bagian kanan.

\section{Analisis Kemasan Antangin}

Kedua kemasan Antangin hampir mirip. Keduanya menggunakan warna kuning sebagai latar belakang. Hal ini bertujuan untuk memberikan nuansa kehangatan. Karena produk ini merupakan obat herbal yang berfungsi untuk meredakan masuk angin dan perut kembung. Perbedaan dari kedua desain kemasan ini terdapat pada bagian campuran utama rempah-rempah. Unsur rempah pada Antangin JRG yaitu jahe, royal jeli, dan gingseng. Dimana terdapat ilustrasi dari rempah tersebut yang dapat dilihat pada bagian kiri desain. Ilustrasi tersebut bertujuan untuk mempertegas dan mengilustrasikan bahan dari obat herbal. Selain ilutsrasi rempah tersebut terdapat juga ilustrasi madu beserta tulisan + madu yang berguna untuk menjelaskan jika obat herbal ini terdapat campurat madu. Unsur madu disini bertujuan untuk menghilangkan persepsi jika obat herbal ini tidak pahit dan bisa langsung diminum tanpa campuran minuman lain. Latar belakang pada ilustrasi menggunakan warna merah yang mewakili dari warna rempah seperti jahe dan gingseng. Warna merah juga digunakan pada tipografi. Dalam hal ini desain pada kemasan Antangin sama dengan desain kemasan tolak angin.

Sedangkan produk Antangin Mint, unsur yang terdapat pada kemasan yaitu extra mint, jahe, dan madu. Dimana terdapat ilustrasi dari rempah tersebut yang dapat dilihat pada bagian kiri desain. Ilustrasi tersebut bertujuan untuk mempertegas dan mengilustrasikan bahan dari obat herbal. Selain ilutsrasi rempah tersebut terdapat juga ilustrasi madu beserta tulisan + madu yang berguna untuk menjelaskan jika obat herbal ini terdapat campurat madu. Unsur madu disini bertujuan untuk menghilangkan persepsi jika obat herbal ini tidak pahit dan bisa langsung diminum tanpa campuran minuman lain. Latar belakang pada ilustrasi menggunakan gradasi warna kuning dan hijau yang mewakili dari warna rempah seperti jahe dan gingseng. Warna merah juga digunakan pada tipografi. Dalam hal ini desain pada kemasan Antangin sama dengan desain kemasan tolak angin. Pada penataan kedua komposisi kemasan dari produk Antangin yaitu asimetris dimana bisa dilihat pada penekanan ilustrasi pada bagian kiri desain yang berat dengan warna merah.

Berbeda dengan kemasan Tolak Angin yang terdapat bendera Indonesaia, pada kemasan Antangin terdapat logo halal yang bisa ditemui pada bagian kiri bawah yang bertujuan untuk mepertegas jika produk ini sudah lulus uji produk halal dari MUI.

\section{KESIMPULAN}

Dari analisa diatas dapat dikatakan, desainer produk kemasan sudah memperhitungkan pasar masing-masing produk jamu atau sirup herbal masuk angin pada saat mendesain khususnya kesan rempah-rempah ilustrasi pada kemasan. Bisa dikatakan produk Antangin membuat desain kemasan yang hampir sama guna untuk pemasaran, karena produk Antangin merupakan produk kompetitor dari produk Tolak Angin yang merupakan produk pertama dari obat herbal.

Untuk produk Tolak Angin antara beberapa produk berbeda bergantung dengan jenis dan khasiat dari masing-masing produk yang sudah 
tertera pada kemasan yaitu + madu dan bebas gula. Untuk Tolak Angin + madu terdapat logo OBAT HERBAL TERSTANDAR, hal ini berbeda pada kemasan produk Tolak Angin bebas gula dimana pada kemasannya terdapat logo JAMU. Pada kedua produk terdapat gambar bendera merah putih yang melambangkan Indonesia dan menonjolkan PT SIDOMUNCUL yang ditulis dengan ukuran font besar diikuti dengan tahun berdirinya yang dimaksudkan untuk menceritakan bahwa PT Sidomuncul sudah lama berdiri dan beredar di pasaran. Sedangkan untuk produk Antangin yang merupakan produk mee too setelah produk Tolak Angin sekilas memiliki kesamaan dengan produk Tolak Angin apabila dilihat dari kemasan dari kedua produk ini, akan tetapi tetap ada perbedaan di antara keduanya yang menjadi ciri khas masingmasing produk. Antangin juga memiliki kemasan yang berbeda bergantung pada jenis dan khasiatnya diantaranya adalah Antangin JRG (Jahe, Royal Jelly, Ginseng) dan Antangin Extra Mint. Hampir sama dengan kemasan produk Tolak Angin, produk Antangin juga memiliki logo OBAT HERBAL TERSTANDAR untuk Antangin JRG sedangkan terdapat logo JAMU pada Antangin Mint.

Semua faktor desain kemasan telah diperhatikan oleh desainer, khususnya aspek grafis pada kemasan masing-masing produk. Meskipun desain Tolak Angin dan Antangin hampir sama tetapi keduanya memiliki perbedaan pada identitas masing-masing produk yang menjadi ciri khas sendiri, terutama karena desain kemasan ini tetap konsisten yang terletak pada warna, gambar dan tipografi yang digunakan..

\section{DAFTAR PUSTAKA}

Feldman, E. B. (1967). Art as Image and Idea. New Jersey: Prentice Hall.

Jefkins, F. (1997). Manajemen Periklanan. Jakarta: Erlangga.

Kartajaya, H. (1996). Marketing Plus 2000: Siasat Memenagkan Persaingan Global. Jakarta: Gramedia.

Kotler, A. (2001). Prinsip-prinsip pemasaran $(12$ Jilid 1). Jakarta: Erlangga.

Kusmiati, A., Astuti, S., \& Suptandar, P. (1999). Teori Dasar Desain Komunikasi Visual. Jakarta: Djambatan.

Metcalf, L., Jeffrey, D. J. E., \& Singh. (2012). A mixedmethods approach for designing marketdriven packaging. Qualitative Market Research An International Journal, 15(3), 268-289.

Nugroho, B. T. (2006). Menambah Daya Tarik Melalui Keindahan.

Silayoi, P., \& Speece, M. (2005). The importance of packaging attributes: a conjoint analysis approach. European Journal of Marketing, 41(11/12), 1495-1517.

Sugiyono. (2013). Metode Penelitian Kuantitatif Kualitatif dan R\&D. Bandung: Alfabeta.

Suptandar, P. (1995). Manusia dan Ruang dalam Proyeksi Desain Interior. Jakarta: UPT Penerbitan Universitas Tarumanegara.

Wang, E. S. T. (2013). The influence of visual packaging design on perceived food product quality, value, and brand preference. International Journal of Retail \& Distribution Management, 41(10), 805-816. 